Gut, 1981, 22, 823-826

\title{
Cytopathic effects in cultures inoculated with material from Crohn's disease
}

\author{
C Ó MORÁIN,* H PRESTAgE, P HARRISON, A J LEVI, AND D A J TYRRELL \\ From the Division of Communicable Diseases and Clinical Sciences, \\ Northwick Park Hospital and Clinical Research Centre, Harrow, Middlesex
}

SUMmARY Rectal biopsy homogenates, faecal samples, and leucocyte rich plasma obtained from 39 patients were inoculated into tissue cultures. A non-transmissible cytopathic effect was observed in cultures inoculated with material from patients with Crohn's disease. In a blind study this cytopathic effect was observed in three specimens from three patients with Crohn's disease, in six specimens from four patients with ulcerative colitis, and six specimens from five patients with upper gastrointestinal disease. The cytopathic effect is unlikely to be associated with the bowel diseases tested. These results are also consistent with the failure of others to isolate a virus by the techniques used. With the limited range of techniques used no evidence was obtained to implicate conventional viruses in the pathogenesis of Crohn's disease.

The aetiology of Crohn's disease remains unknown. Recent reports suggest that a virus may be the causative agent. Aronson et al. ${ }^{1}$ have isolated a small RNA virus in cell cultures inoculated with tissue from cases of Crohn's disease, but also found a similar virus in cultures inoculated with control tissue. More recently the same group have reported the isolation of a reovirus-like agent exclusively from Crohn's disease tissue homogenates. ${ }^{2}$ Gitnick et $a .^{3-5}$ recorded a cytopathic effect on rabbit ileal tissue cultures inoculated with tissue from Crohn's disease; this was serially transmitted for at least three and up to 25 passages. The cytopathic effect was inhibited by low dilutions of serum from patients with Crohn's disease. The aim of this study was to detect a cytopathic effect induced by Crohn's disease tissue and to characterise and isolate viruses if present.

\section{Methods}

The investigation was carried out in two stages. The first was to determine if a cytopathic effect was induced by inoculating Crohn's disease tissue into cell cultures used for the isolation of common viruses. The second was a blind study to see if any cytopathic effect induced was associated with Crohn's disease or ulcerative colitis.

*Address for correspondence: C $ठ$ Moråin, Division of Clinical Sciences, Clinical Research Centre, Harrow, Middlesex, HA1 3UJ.

\section{PATIENTS}

In a pilot study 19 patients were investigated. They included 12 patients with active Crohn's disease who required hospitalisation and were receiving only general supportive therapy at the time. The diagnosis of Crohn's disease was made on typical clinical and radiological features in seven patients and characteristic histological features in tissue obtained at laparotomy or on rectal biopsy in five patients. Seven patients with active ulcerative colitis, diagnosed on rectal biopsy histology, were also studied.

In the second blind study another 20 patients were investigated. Eight had Crohn's disease, four of these had rectal involvement confirmed by finding characteristic histological features on rectal biopsy and four had small bowel disease. Six patients had ulcerative colitis and six upper gastrointestinal dyspepsia with normal rectal mucosa on histological examination.

PREPARATION OF SPECIMENS FOR INOCULATION INTO TISSUE CULTURE

\section{Rectal biopsy}

The biopsy tissue was divided into two. One half was sent for histological examination and the other was placed immediately into virus transport medium which consisted of nutrient broth (Oxoid No. 2) 823 
$10 \mu \mathrm{g} / \mathrm{ml}$ amphotericin B and was then stored at $-70^{\circ} \mathrm{C}$. The tissue was thawed and ground up with a glass tissue homogeniser (on ice) in a total volume of $2 \mathrm{ml}$ virus transport medium. It was not centrifuged and surplus homogenate was stored at $-70^{\circ} \mathrm{C}$. Twenty millilitres venous blood samples were mixed with $0.4 \mathrm{ml}$ sterile preservative-free heparin and $2 \mathrm{ml}$ dextran (Dextran 70 Injection BP in $0.9 \%$ sodium chloride, Fisons Ltd, Pharmaceutical Division) and sedimented at $37^{\circ} \mathrm{C}$ for 30 minutes. The leucocyte-rich plasma was removed and inoculated into tubes immediately or stored at $-70^{\circ} \mathrm{C}$

\section{Faeces}

Faecal specimens were collected fresh in sterile containers at sigmoidoscopy and stored immediately at $-70^{\circ} \mathrm{C}$. The specimen was thawed and suspended $(10 \% \mathrm{w} / \mathrm{v})$ in nutrient broth (Oxoid No. 2). The suspension was centrifuged at $2500 \mathrm{~g}$ for 25 minutes. The supernatant was removed, and antibiotics to a final concentration of $1000 \mathrm{IU} / \mathrm{ml}$ penicillin and streptomycin and $10 \mu \mathrm{g} / \mathrm{ml}$ amphotericin B were added. This mixture was centrifuged at $10000 \mathrm{~g}$ at $4^{\circ} \mathrm{C}$ for 30 minutes and the supernatant was retained. Surplus supernatant was stored at $-70^{\circ} \mathrm{C}$.

\section{Cell cultures}

Ohio HeLa cells were grown in Eagle's BME diploid medium (Gibco) plus $10 \%$ fetal calf serum, $2 \mathrm{mM}$ 1-glutamine (BDH), $100 \mathrm{IU} / \mathrm{ml}$ penicillin and streptomycin, $4 \%$ tryptose phosphate broth (Difco), and $43.8 \mathrm{mg} / 1$ sodium bicarbonate (BDH), and maintained in a similar medium but with $2 \%$ fetal calf serum, $2 \%$ tryptose phosphate broth, and $58.4 \mathrm{mg} / \mathrm{l}$ sodium bicarbonate.

MRC5 cells (passages 18-25) were grown on Eagle's diploid medium (Gibco) plus $10 \%$ fetal calf serum, $29.2 \mathrm{mg} / 1$ sodium bicarbonate, $2 \mathrm{mM}$ l-glutamine (BDH), and penicillin and streptomycin $(\mathrm{P} / \mathrm{S}) \quad 100 \mathrm{IU} / \mathrm{ml}$. For maintenance medium the concentration of fetal calf serum was reduced to $2 \%$. Subcultures (1:3) of HeLa and MRC5 cells were made at weekly intervals and the maintenance medium on tube cultures of all three cell lines was changed weekly.

Baboon kidney cells (passage 2) were grown in 199 medium (Flow Laboratories) plus $5 \%$ newborn calf serum, $2 \mathrm{mM}$ l-glutamine (BDH), $100 \mathrm{IU} / \mathrm{ml}$ penicillin and streptomycin, and $29.2 \mathrm{mg} / \mathrm{l}$ sodium bicarbonate, and maintained on the same medium with $2 \%$ fetal calf serum and $36.5 \mathrm{mg} / \mathrm{l}$ sodium bicarbonate.

Cell cultures were all prepared in stationary stoppered glass test tubes and were maintained in air at $37^{\circ} \mathrm{C}$. They were inoculated with $10^{5}$ cells and used when confluent.

\section{Inoculation of cell cultures and attempted passage}

A volume of $0.2 \mathrm{ml}$ was added to each of three tubes containing $1 \mathrm{ml}$ of recently changed medium. The medium in tubes inoculated with leucocyte-rich plasma or faeces supernatant was changed after three hours of incubation. Maintenance medium was changed weekly. From most positive cultures $0.2 \mathrm{ml}$ of medium and cells was inoculated into each of another three cultures. No serial passage was achieved.

Observation of cells

Cell monolayers were observed daily (except at weekends) for three weeks under a low-powered

Table 1a Summary of occurrence of cytopathic effect in cultures inoculated with material from cases of gastrointestinal disease

\begin{tabular}{llll}
\hline Disease & Faeces & $\begin{array}{l}\text { Leucocyte-rich } \\
\text { plasma }\end{array}$ & $\begin{array}{l}\text { Rectal } \\
\text { biopsies }\end{array}$ \\
\hline Crohn's & $1 / 7(1 / 7)$ & $2 / 8(0 / 8)$ & $0 / 8(0 / 8)$ \\
Ulcerative colitis & $4 / 6(0 / 6)$ & $1 / 6(0 / 6)$ & $1 / 6(1 / 6)$ \\
Upper G1 & $3 / 6(1 / 6)$ & $1 / 6(0 / 6)$ & $2 / 6(2 / 6)$ \\
\hline
\end{tabular}

Numerator: number of instances in whieh cytopathic effect was observed. Denominator: number of cases tested.

Numbers in parentheses indicate extensive cytopathic effect-that is, the majority of cells in the culture were rounded up.

Table Ib Occurrence of cytopathic effect in cultures inoculated with material from cases of gastrointestinal disease.

\begin{tabular}{rllll}
\hline Patient no. & Disease & Faeces & $\begin{array}{l}\text { Leucocyte-rich } \\
\text { plasma }\end{array}$ & $\begin{array}{l}\text { Rectal } \\
\text { biopsies }\end{array}$ \\
\hline 1 & Crohn's & - & - & - \\
2 & Crohn's & - & - & - \\
3 & Crohn's & $* *$ & - & - \\
4 & Upper GI & - & $*$ & - \\
5 & Crohn's & - & $*$ & - \\
6 & Crohn's & - & - & - \\
7 & Ulcerative colitis & $*$ & $*$ & - \\
8 & Upper GI & $*$ & - & - \\
9 & Ulcerative colitis & $*$ & - & - \\
10 & Upper GI & $*$ & - & $* *$ \\
11 & Upper GI & $* *$ & - & - \\
12 & Ulcerative colitis & $*$ & - & $*$ \\
13 & Ulcerative colitis & $*$ & - & - \\
14 & Upper GI & $*$ & - & - \\
15 & Upper GI & - & - & - \\
16 & Crohn's & - & - & - \\
17 & Ulcerative colitis & - & - & - \\
18 & Ulcerative colitis & - & - & - \\
19 & Crohn's & - & - & - \\
20 & Crohn's & NT & $*$ & \\
\hline
\end{tabular}

-: no cytopathic effect.

*: cytopathic effect.

**: extensive cytopathic effect-that is, the majority of the cells in the culture were rounded up.

NT: not tested. 


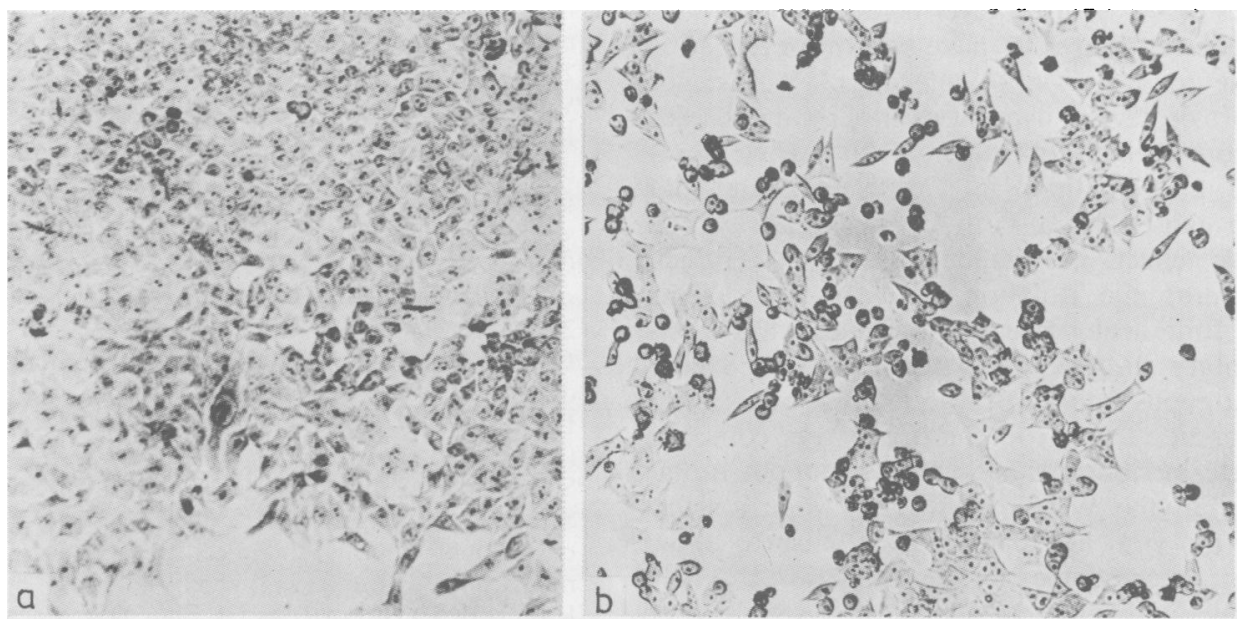

Figure HeLa cell cultures six days after inoculation (a) control cells $(b)$ a cytopathic effect induced by a faecal sample from a patient with acute Crohn's disease.

inverted light microscope, and the proportion of cells exhibiting a cytopathic effect, and the number of cytopathic effect foci were estimated.

\section{Results}

In the pilot study a cytopathic effect was observed in HeLa cell cultures inoculated with three of eight rectal biopsy homogenates, three of five leucocyterich suspensions, and four of nine stool samples obtained from 12 patients with Crohn's disease. A cytopathic effect was also observed in tissue cultures inoculated with material from two of seven patients with ulcerative colitis; one was induced by a rectal biopsy homogenate and the other by a stool sample. On retesting the cytopathic effect was again observed in nine of 12 previously positive specimens. Stool samples from three of eight patients with Crohn's disease and one of four patients with ulcerative colitis induced a cytopathic effect in MRC5 cells. A rectal biopsy homogenate from one of the patients with ulcerative colitis induced a cytopathic effect in the MRC5 tissue culture. The specimens that induced a cytopathic effect on MRC5 tissue cultures also induced the cytopathic effect in HeLa cells. All specimens were also inoculated into baboon kidney cells but no cytopathic effect was observed. In affected HeLa cells localised regions of refractile rounded cells appeared at the bottom of the tube. At a later stage clumps of completely rounded refractile cells adhered to the monolayer (Figure). In MRC5 cultures individual cells appeared narrowed and the surface was irregular; gaps appeared between them; there was no increase in refractility. These changes occurred between three and 21 days after inoculation. The control tissue cultures remained healthy for longer but similar changes occurred in them eventually.

In the second study HeLa cells alone were inoculated (Table la and b). In the Crohn's group a cytopathic effect was observed in three of the tissue cultures. This was induced by one stool sample and two leucocyte-rich specimens obtained from three different patients. A similar cytopathic effect was observed in six tissue cultures inoculated with material from four patients with ulcerative colitis (four stool samples, one leucocyte-rich suspension, and one rectal biopsy). Three stool samples, one leucocyte-rich suspension, and two rectal biopsies obtained from five of the patients with upper gastrointestinal disease produced a cytopathic effect.

\section{Discussion}

In our preliminary study, material from six of the 12 patients with Crohn's disease and from two of seven patients with ulcerative colitis produced a cytopathic effect. This was most noticeable and more frequently observed in HeLa cell tissue culture. It was impossible to pass the cytopathic effect serially. The blind study revealed that a similar cytopathic effect was observed even more often in tissue cultures inoculated with material from control subjects. In view of this we report no results on tests of whether the cytopathic effect was mediated by something in the tissue extracts with the 
properties of a virus. Nevertheless, others have failed to detect a virus or have shown a cytopathic effect due to a non-viral substance. ${ }^{6-8}$ Evidence in support of a viral hypothesis in Crohn's disease comes from animal transmission studies, ${ }^{9-14}$ chromosomal abnormalities in Crohn's disease that could be caused by a virus, ${ }^{1-5}$ and reports of a cytopathic effect in tissue cultures. ${ }^{1-5}$ Gitnick et al. ${ }^{3}$ report the isolation of cytopathic agents from all four ileal tissue homogenates of patients with Crohn's disease inoculated into WI-38 cells and continuous rabbit ileal cells but none from control tissue. The cytopathic effect was complete in a shorter period of time in the continuous rabbit ileal than in the WI-38 cells. They were able to cultivate the viral agent in sufficient titre to allow electron microscopic characterisation. ${ }^{4}$ The appearance and physical chemical properties of the agent resembled those of a picornavirus. More recently the same group have observed the cytopathic effect in the majority of tissue specimens obtained from patients with Crohn's disease, ulcerative colitis, carcinoma of the bowel, and fiom some other controls. Serum from patients with Crohn's disease inhibited the Crohn's disease isolates but did not inhibit the ulcerative colitis agents or the agents found in other controls. ${ }^{5}$ Nevertheless, we cannot exclude the possibility that the virus propagated was picked up in the laboratory and another group using identical techniques with continuous rabbit ileal cells were unable to demonstrate a transmissible cytopathic effect with Crohn's disease tissue. ${ }^{8}$ In recent studies bowel filtrates from patients with Crohn's disease, ulcerative colitis and from some 'control' cases induced a cytopathic effect in WI-38 tissue cultures: furthermore, they failed to reveal any serological difference between normal and inflammatory bowel disease patients using infected cell cultures as target organs. ${ }^{16}$ Thus our studies indicate that the cytopathic effect observed is not associated with the bowel disease tested, and we cannot confirm that it is due to a virus by serial passage as described by others.

\section{References}

'Aronson MD, Phillips CA, Beeken WL, Forsyth BR. Isolation and characterisation of a viral agent from intestinal tissue of patients with Crohn's disease and other intestinal disorders. Progr Med Virol 1975; 21: 165-76.

${ }^{2}$ Whorwell PJ, Phillips CA, Beeken WL, Little PK, Roessner KD. Isolation of reovirus-like agents from patients with Crohn's disease. Lancet 1977; 1 : 1169-71.

${ }^{3}$ Gitnick GL, Arthur MH, Shibata I. Cultivation of viral agents in Crohn's disease. Lancet 1976; 2: 215-7.

'Gitnick GL, Rosen VJ. Electron microscopic studies of viral agents in Crohn's disease. Lancet 1976; 2: 217-9.

'Gitnick GL. Infectious agents in inflammatory bowel disease. 2nd International Workshop on Crohn's Disease. De Baak Noordwijk/Zee, Holland 25-28 June 1980. (In press)

${ }^{6}$ Schneierson SS, Garlock JH, Shore B, Stuart WD, Steinglass M, Aronson B. Studies on the viral etiology of regional enteritis and ulcerative colitis: a negative report. Am J Dig Dis 1962; 7: 839-43.

'Kyle J, Bell TH, Porteous IB, Blair DW. Factors in the aetiology of regional enteritis. Bull Soc Int Chir 1963; 22: $575-84$.

${ }^{8}$ Phillpotts RJ, Herman-Taylor J, Brooke BN. Virus isolation studies in Crohn's disease: a negative report. Gut 1979; 20: 1057-62.

${ }^{9}$ Mitchell DN, Rees RJW. Agent transmissible from Crohn's disease tissue. Lancet 1970; 2 : 168-71.

${ }^{10}$ Cave DR, Mitchell DN, Kane SP, Brooke BW. Further animal evidence of a transmissible agent in Crohn's disease. Lancet 1973; 2: 1120-2.

${ }^{11}$ Cave DR, Mitchell DN, Brooke BN. Experimental animal studies in the etiology and pathogenesis of Crohn's disease. Gastroenterology 1975; 69: 618-24.

${ }^{12}$ Taub RN, Sachar D, Janowitz H, Siltzbach LE. Induction of granulomas in mice by inoculation of tissue homogenates from patients with inflammatory bowel disease and sarcoidosis. Ann NY Acad Sci 1976; 278: $560-4$.

${ }^{13}$ Cave DR, Mitchell DN, Brooke BN. Induction of granulomas in mice by Crohn's disease tissues. Gastroenterology 1976; 75: 632-7.

${ }^{14}$ Das KM, Valenzuela I, Morecki R. Crohn's disease lymph node homogenates produce murine lymphoma in athymic mice. Proc Natl Acad Sci USA 1980; 77: 588-92.

${ }^{15}$ Emerit I, Emerit J, Levy A, Keck M. Chromosomal breakage in Crohn's disease: anticlastogenic effect of D-penicillamine and L-cysteine. Hum Genet 1979; 50: $51-7$.

${ }^{16}$ Strickland RG, McLaren LC. Studies of the in vitro cytopathic effect of inflammatory bowel disease tissue preparations. In: Pena, Weterman, Booth CC, Strober, eds. Recent advances in Crohn's disease. Martinus Milhoff Publ, The Hague, 1981 : 246-51. 